\title{
Forest archipelagos: A natural model of metacommunity under the threat of fire ${ }^{\text {is }}$
}

\author{
Marcel S. Coelho ${ }^{\mathrm{a}, \mathrm{b}, *}$, Frederico de Siqueira Neves ${ }^{\mathrm{c}}$, Lucas Neves Perillo ${ }^{\mathrm{c}}$, \\ Leonor Patrícia Cerdeira Morellato $^{b}, \mathrm{G}$. Wilson Fernandes ${ }^{\mathrm{a}}$ \\ a Laboratory of Evolutionary Ecology and Biodiversity, CP 486, ICB/Federal University of Minas Gerais, 30161-970 Belo Horizonte, MG, Brazil \\ ${ }^{\mathrm{b}}$ UNESP - Universidade Estadual Paulista, Instituto de Biociências, Departamento de Botânica, Laboratório de Fenologia, 13506-900 Rio Claro, SP, Brazil \\ ${ }^{\mathrm{c}}$ Laboratory of Insect Ecology, CP 486, ICB/Federal University of Minas Gerais, 30161-970 Belo Horizonte, MG, Brazil
}

\section{A R T I C L E I N F O}

\section{Article history:}

Received 21 December 2016

Received in revised form 30 March 2017

Accepted 31 March 2017

Edited by Fernando A O Silveira

Available online 4 April 2017

\section{Introduction}

One of the most important precepts of the modern conservation biology is the synergism between the efforts to protect speciose ecosystems and the ecological processes responsible for maintaining important environmental services (Kareiva and Marvier, 2012). Although the Brazilian vegetations are well studied, a unique ecosystem has received little attention by the scientific community and policy makers. Locally called Capões de Mata - hereafter Atlantic forest islands, or simply forest islands - the natural islands of forests on the open grassland matrix of Espinhaço mountain range are examples of an ecosystem with relevant biodiversity associated to the protection of headwaters. The headwaters under forest islands feed important Brazilian river basins. The ecological regime - e.g. ombrophilous or semi-deciduous - dynamic of genesis and expansion, the existence of meta-community processes, and which ecoregions plays a major influence on its structure and composition - if Atlantic Rainforest or Cerrado (i.e., Brazilian savanna) - have only recently started to be deeply discussed (Coelho et al., 2016).

\footnotetext{
This article is part of a special issue entitled Plant life in campo rupestre: new lessons from an ancient biodiversity hotspot published at the journal FLORA 238C.

* Corresponding author at: UNESP - Universidade Estadual Paulista, Instituto de Biociências, Departamento de Botânica, Laboratório de Fenologia, 13506-900 Rio Claro, SP, Brazil.

E-mail addresses: marcel.s.coelho@gmail.com (M.S. Coelho),

fred.neves@gmail.com (F. de Siqueira Neves), lucasnevesperillo@gmail.com

(L.N. Perillo), patricia.morellato@gmail.com (L.P.C. Morellato),

gw.fernandes@gmail.com (G.W. Fernandes).
}

Despite occurring on mountaintops and in a transition zone between two phytogeographic domains, they are predominantly under influence of the Atlantic Rainforest, a biodiversity hotspot (Myers et al., 2000). The Atlantic Forest Act (Federal Law 11.428/2006) recognizes ombrophilous and semi-deciduous forests as part of the Atlantic Forest domain. However, the scale size of the thematic map which the law is mostly based on does not allow the recognition of small forest disjunctions, as the Atlantic forest islands from Espinhaço range. Although these natural islands of tropical Atlantic forest have been mostly neglected, they are part of critically endangered hotspot of biodiversity and harbor several endangered species in need of study.

The forest islands of Espinhaço Range are surrounded by a matrix dominated by the rupestrian grasslands, locally called campo rupestre, a fire-prone vegetation mosaic adapted to burning and largely accept as a component of cerrado savanna domain (but see Silveira et al., 2016). While fire is an important ecological force driving the evolution of the dominant grasslands and scrublands of rupestrian grasslands and its component species (Alvarado et al., 2017), it can be a significant threat to the conservation of forest islands. This discrepancy poses a dilemma to fire management policy in a mosaic of fire-sensitive and fire-tolerant vegetation.

Considering the above scenario, here we address the ecology of natural forest islands and we (i) discuss the disjunction from the Atlantic Rainforest and their conservation status; (ii) argue that fire is a major threat to forest islands conservation, proposing possible management strategies, and (iii) highlight the relevance of the islands as suppliers of ecosystem services and as an unexploited natural model for testing ecological and evolutionary hypotheses (e.g., metacommunity dynamics). 


\section{Atlantic forest islands: location and landscape dynamics}

The mountaintops of the Espinhaço Range are one of the few tropical areas that have remained stable during past climate changes, with emphasis on the latest considerable changes dating back to the Pleistocene period (Barbosa and Fernandes, 2016). It is likely that this ecological stability has been a driver of its high endemism (Hopper, 2009; Barbosa and Fernandes, 2016). The southern region of Espinhaço is influenced by the humid Atlantic tropical mass on its eastern face, as well as at high altitudes, leading to elevate rates of rainfall/humidity and stabilization in the form of Fronts of Stationary Nebulosity (Streher et al., 2017). The Atlantic tropical mass carries humidity from the Atlantic coast via jet streams, which fall as rain at high altitudes in the southern region of the Espinhaço Range, feeding specially the basins of the Doce river (to the east) and the São Francisco river (to the west). Thus, the Atlantic rainforest acts on the eastern face (windward), especially in the drainage zones, and maintains an influence over the higher altitudinal strata of the western face (leeward). As a result of the distinct climatic conditions, this regional landscape hosts elements of the Atlantic Forest (sensu Oliveira and Fontes, 2000) to the east and elements of the Cerrado to the west. Unlike the eastern face, which is mostly covered by semi-deciduous forest and, when close to the drainage and wet zones, cloud forests, the western face hosts a mosaic of vegetation' physiognomies associated with the Cerrado. The higher altitudes - mountaintops and plateaus - represent transitional zones between the two phytogeographic domains (Cerrado and Atlantic Forest) and are dominated by rupestrian grasslands (Silveira et al., 2016), gallery forests and forest islands (see Coelho et al., 2016 for a review).

The forest islands of the Espinhaço are natural islands of forest with floristic compositions very similar to the semi-deciduous forests of the Atlantic Forest domain, but with a climate system associated with cloud forests (Meguro et al., 1996; Souza, 2009; Valente, 2009; Coelho et al., 2016). These forest islands are surrounded by rupestrian grasslands (old climatically-buffered infertile landscapes - OCBIL) (Silveira et al., 2016), and established on well drained, deep and low acidic clay soil patches (Figs. 1 and 2). Therefore, the forest islands fit into environmentally suitable zones formed by quite specific soil and climate conditions (Fronts of Stationary Nebulosity), characteristics of edaphoclimatic vegetation (Rizzini, 1997). This forest ecosystem can establish in regions close to the mountains plateaus and ridges ( $\sim 1200 \mathrm{~m}$ a.s.l.) that make up the Espinhaço Range, only under the combination of these specific environmental conditions (Coelho et al., 2016).

The landscape location and dynamics represent a rare natural opportunity to test hypotheses under relevant ecological frameworks as those related to the island biogeography and metacommunity theories (Leibold et al., 2004; Thompson, 2005). The forest archipelagos are composed by forest islands abruptly separated by a matrix of rupestrian grasslands, both comprising native ecosystems. The forest islands are of different sizes, shapes and distances to the nearest island or to the continuous forest (Fig. 2). This natural landscape feature bears similarities to other novel and fragmented ecosystems due to their high level of isolation and may bring some insights, for instance, into the effects of isolation on plant reproduction (Hagen et al., 2012). Important ecological lessons could be drawn and applied to the dominant landscape realities under conservation threat. The effects of landscape configuration on structuring communities could also be emphasized under the light of principles derived from niche theory and speciessorting models where species differ in their responses to distinct environmental conditions (Chase and Leibold, 2003). Both, dispersal processes and habitat conditions for species establishment are fundamental to understanding how communities are structured and their level of integration among islands (Jamoneau et al., 2011).

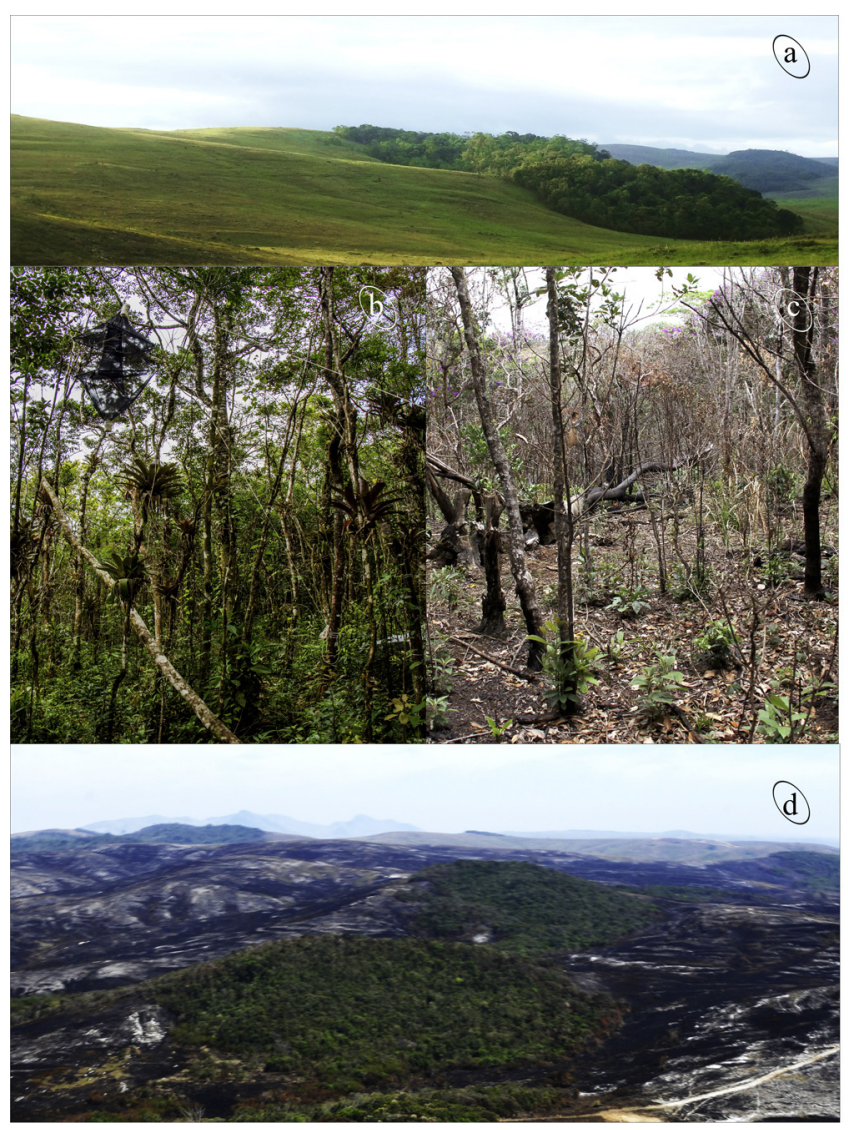

Fig. 1. Atlantic Forest Islands from Serra do Cipó, south Espinhaço Range, Minas Gerais, Brazil. ab. Outside and inside views from typical forest islands; cd. Inside and outside views from a typical forest islands after a fire event.

Therefore, how one ecosystem gives place to the other has been recently debated in the literature, especially in the vegetations of Páramos where is clear the transition between grasslands, at the top, and forest ecosystems, at the bottom of mountains (Rehm and Feeley, 2015). The drivers behind the maintenance of these ecotones could be better understood in natural laboratories such as the forest islands.

\section{Ecosystem dynamics and environmental services}

By forming archipelagos of forest amid grassland ecosystems, the forest islands host a phylogenetically and functionally distinct flora from the surrounding matrix, increasing local and regional species diversity, and likely, serving as refuge for the local fauna (Pereira et al., 2017). Despite the existence of many animal groups endemic to the rupestrian grassland (see Fernandes, 2016), as well as those endemic to the forest islands, evidence suggest the existence of a fauna flow between the two physiognomies (Pereira et al., 2017); especially from groups responsible for ecosystem functions, such as pollinators.

Preliminary data from long-term research project (Long term ecological research from rupestrian grasslands -CRSC) points out to the existence of a dynamic of insect metacommunities among forest islands (Pereira et al., 2017). The rupestrian grassland surrounding the forest islands seem to play a key role in maintaining diversity due to its permeability and resource supply. However, we do not know yet the function of forest islands as connectors/refuges as well as the isolation level considering the complex vegetation of rupestrian grasslands mosaic, and its importance in providing resources as flowers, fruits and leaves, places to rest and nest. For- 


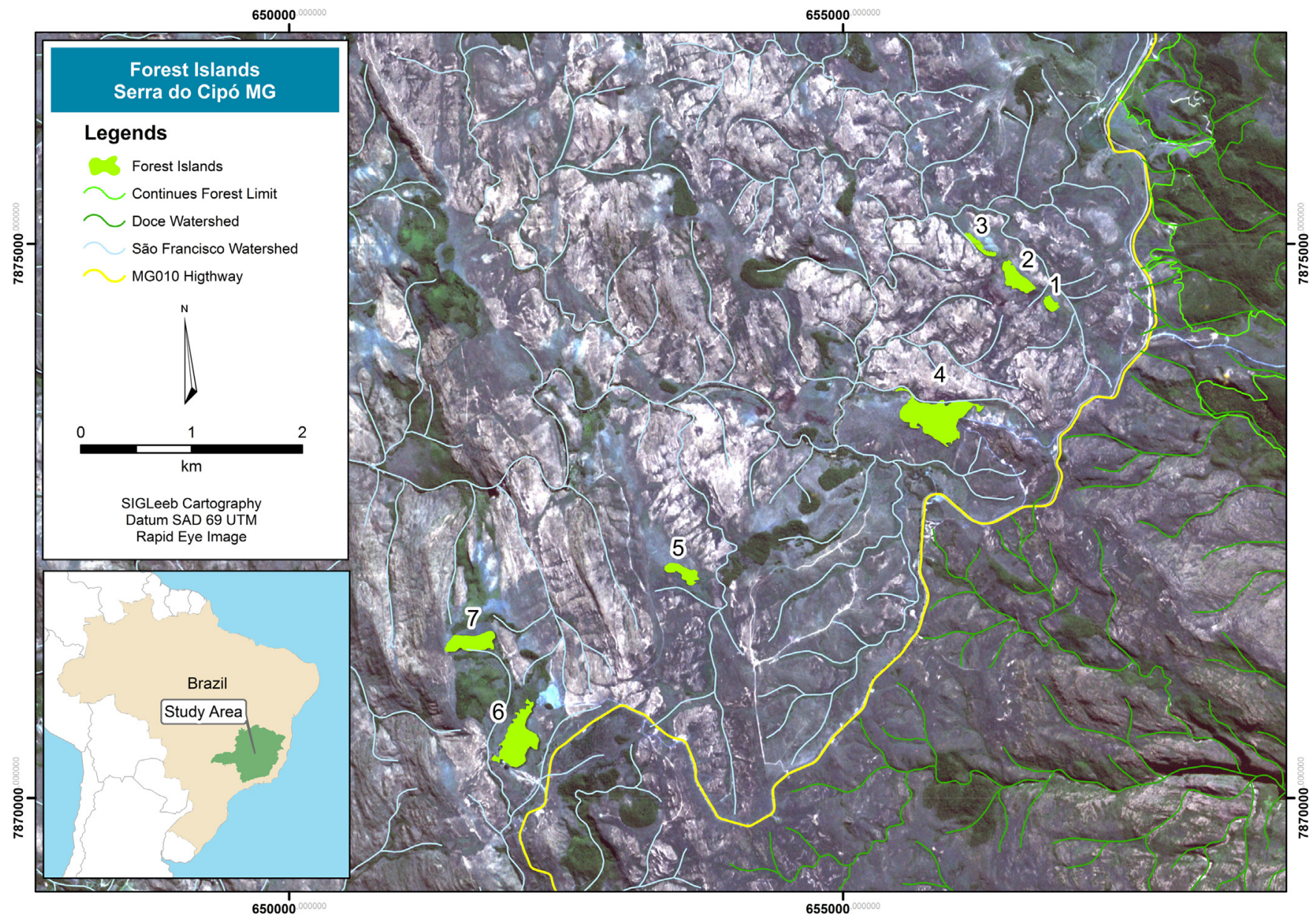

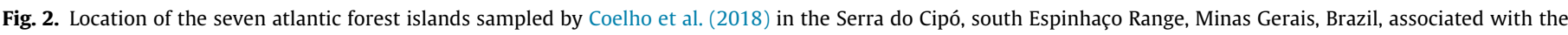
basins and sub-basins of the Rio São Francisco and Rio Doce rivers (source: Minas Gerais State Water Management Institute).

est islands are likely the nesting place and refuge for many animals, most of them - such as large bees and hummingbirds - are the most important long-distance pollinators of many species from the surrounded grasslands (Carstensen et al., 2014), and supporting the diversity of ecological interactions. For instance, hummingbirds pollinate up to $13 \%$ of species while large bees may account for $70 \%$ of pollination services in this ecosystem (Guerra et al., 2016) and may use the forest as shelter or nest. That proportion does not take into account the pollinators specialists of forest island species per se. Forest islands also host most of small mammals and several birds that also play a key role as seed dispersers (Guerra et al., 2016).

The permeability of the landscape can be altered by the plant community phenology (driven by cold winters and humid summers), as well as the action of frequent fire occurrence (Figueira et al., 2016; Alvarado et al., 2017; Streher et al., 2017). Besides their ecological importance, the forest islands establish into humid locations, with well-drained soils, associated with springs and streams (Coelho et al., 2016). The protection service of water intake environments is important, the springs responsible for feeding two of the most important Brazilian river basins, which are responsible for much of the water supply of some of the major Brazilian cities, such as Belo Horizonte (see Fig. 2, Silveira et al., 2016). Those basins are already environmentally compromised by human occupation, fishery overexploitation, exotic species introduction, constant sedimentation and damage on rivers' headwaters (see Galindo-Leal and Câmara, 2005), including one of the largest Brazilian environmental disaster, a mud tsunami caused by a mining dam rupture that invaded Rio Doce basin on 2015 (Fernandes et al., 2016). According to the Brazilian forest code (Law 12.651/2012), all springs, no matter whether perennial or seasonal, as well as mountaintops must be permanently protected. The same can be applied for gallery forests. According to the scientific definition, forest islands must be under the very restrictive terms of use as described in the Atlantic Forest Act (Federal Law $N^{\circ} 11.428 / 2006$ ) and treated as permanent protection area by the Brazilian forest code (Federal Law $\mathrm{N}^{\circ} 12.651 / 2012$ ). Hence, those laws could guarantee protection of a high number of endangered species - the sampling of the forest islands already recorded 18 plant species under some threaten categories (Martinelli and Moraes, 2013). Recent findings detected important differences in species composition between gallery and the forest islands (Coelho et al., 2016), and this diversity patterns have strong implications to conservation strategies deepening on a holistic view of the landscape complexity.

\section{Fire: the main threat to conservation}

Fire stands out as one of the most serious threat to forest islands. Fire has been an important evolutionary factor in savannas and grasslands, as its effects exert a strong environmental filter on forest cover. Many studies have demonstrated the role of fire in re-shaping the borders of savannas as well as functional plant adaptations driving from population to ecosystems (Hoffmann et al., 2003; Veldman et al., 2015; Dantas et al., 2016).

There are three main drivers that control the boundaries between the savannas and other physiognomies (e.g. wet forests): 
climate, soil and fire. From a strictly climatic point of view, the forests that now occupy approximately $25 \%$ of the Earth's surface have the potential to expand to at least $50 \%$ area, especially covering parts of the savannas of South America and Africa (Bond et al., 2005; Veldman et al., 2015). The species comprising the forests have functional advantages over their congeneric savanna species because they have faster growth and higher productivity rates, altering the balance between the boundaries of the ecosystems (Dantas et al., 2016).

Soil may also play an important role in savanna-forest boundaries, especially under similar climate (Bond, 2010). Although some regions covered by savanna formations have a sufficient amount of nutrients for forest development in the deeper soil layers, the granulometric structure and shallow soils of rupestrian grassland are factors restricting forest expansion (Valente, 2009). The third driver is the intense and frequent occurrence of fires (Alvarado et al., 2017). Fire plays a key role in controlling forests expansion, generating environmentally suitable zones that only adapted species could occupy (Hoffmann et al., 2003; Rossatto et al., 2009). Fire is a strong environmental filter and only groups of species with specific traits are able to maintain the composition, structure and ecological dynamics of fire-prone vegetation (Veldman et al., 2015). Savanna and associated vegetation have fire resistance traits (e.g. thicker barks, sclerophylly, underground storage organs), which, in conjunction with the environmental characteristics, make savannas functionally distinct from forests (Miatto et al., 2016). In the absence of fire, fire-dependent vegetation (Bond et al., 2005; Dantas et al., 2016) suffers changes in species composition, structure and dynamics. On that new condition of fire suppression, fire-sensitive species enhance establishment over other species due to its physiological advantages (e.g. higher growth rates), changing the groups of species, canopy formation and eliminating herbaceous-shrub component (main fuel for fire occurrence and intensification) (Bond, 2008; Veldman et al., 2015).

Those particular plant communities are confined to specific soil patches that support dense and moist vegetation, composed of species more characteristic of the Atlantic Rainforest domain (Coelho et al., 2016). Tree species reaches the mountaintops, scattered through the gallery forests, stemming predominantly from the eastern face of the Espinhaço Range (Meguro et al., 1996; Souza, 2009; Valente, 2009; Coelho et al., 2016). The increase in frequency and intensity of anthropogenic fires in the last decades (Alvarado et al., 2017) have been causing a strong effect on these islands, reducing them from their borders. The forest islands have likely gradually decreased in area over dry seasons accompanied by frequent and intense fire events.

The fire burns away the array of rupestrian grassland, a vegetation high resilience to fire, with important adaptations, such as below-ground biomass storage and sclerophylly (Figueira et al., 2016; Silveira et al., 2016). The edges of the forest islands are strongly impacted because of the death of the trees, which are not fire-resistent, hence promoting a succession zone (Staver et al., 2011; Coelho et al., 2016) or even excluding the forest vegetation (Fig. 1c,d). All studies carried out on forest islands have reported on the impacts of fire (see Coelho et al., 2016 for a review). Because forest islands are high-humidity environments, with the central regions of the forest islands with large trees, fire causes greater impacts to the edges of the islands (Tabarelli et al., 2008). In a study conducted on forest islands at Rio Preto State Park (PERPreto), also located in the Espinhaço Range, Souza (2009) found significant floristic differences between the edge and the central regions of the forest islands. Tree density, stem diameter, average height of individual trees, richness and species diversity varied noticeably between the border and the central areas of the forest islands evaluated, indicating that the forest islands present a clear edge effect and fire-sensitive species (Souza 2009).
In a study of soils in a grassland-forest vegetation gradient in Serra do Cipó, Valente (2009) identified strong differences in the physical and chemical soil properties collected at different points in the forest islands. The soil conditions in the central areas were more favorable to the establishment of late successional species than in the edges (Valente, 2009).

Another likely consequence is an increase in permissiveness to biological invasion and homogenization among forest islands (Arroyo-Rodriíguez et al., 2013). Despite the inventories conducted up to date at the forest islands have no records of invasive species (Coelho et al., 2016), some pioneer species were already found, indicating the presence of disturbance (e.g., Eremanthus erithropappus) (Coelho et al., 2016). We suggest a stabilization of the area occupied by the forest islands in the unlikely scenario of total fire suppression, as a consequence of the strong connection on soil patches. On the other hand, the increase in fire intensity and extension could eventually lead to the extinction or drastic reduction of the forest islands, giving space to smaller islands composed predominantly by opportunistic and fast growth species. We have also observed over the last years that deep-burned edges of some forest islands/patches at Serra do Cipó have not regenerated two years after fire (Fig. 3). This instable scenario facilitates cattle access to the forests interior. Therefore, the fires regime on the Espinhaço mountaintops (see Alvarado et al., 2017), in synergy with other factors, may threaten the maintenance of the functions and ecosystem services of the forest islands, and have to be taken into account due to the contrasting roles on the rupestrian grassland matrix.

\section{The need to conservation policies}

Despite their relevance from an ecological and economic perspective, the forest islands of the Espinhaço Range are under increasing threat. Local landscape uses are numerous and can vary from pasture for livestock to selective logging of individual tree species for firewood (Kolbek and Alves, 2008). Because these plant formations are home to a variety of ferns and herbaceous angiosperms (orchids, bromeliads and aroids), the illegal trade of these species for use in landscaping is common (Coelho et al., 2016).

The dissemination of knowledge about the functions and services of the ecosystem performed by the forest islands associated with the Espinhaço Range is imperative. Moreover, increased monitoring by environmental agencies is a sine qua non condition to curb the illegal collection of species and wood for landscaping. The monitoring may also reduce fire frequency. In the face of small dimensions of the forest islands the use of unmanned aerial vehicles or drones is an alternative strategy to monitor and detect changes in the landscape over time (Fig. 3). However, when fire is inevitable, it should be managed. The implementation of firebreaks could be an alternative (Ramos-Neto and Pivello, 2000). The main disturbance responsible for a transitory increase in the biodiversity is windstorms causing mostly tree falls (Coelho et al., 2016). Fire suppression may lead to more intense and extensive fires (Alvarado et al., 2017), which imposes severe threats to forest islands. The impossibility of deploying firebreaks in all forest islands over the Espinhaço range suggests the development of strategies targeting specific islands to manage, based on their ecological dynamics, role as connectors and providers of important ecosystem services.

The forest islands must be clearly recognized as a vegetation type under the umbrella of the very restrictive terms of use provided by the Atlantic Forest Act (Federal Law $N^{\circ} 11.428 / 2006$ ) and also treated as Permanent Protection Area (PPA) by the Brazilian forest code (Federal Law No 12.651/2012) (Coelho et al., 2016). Thereby, even the archipelagos of natural forests lying outside protected areas would be fully protected. Brazilian society must learn about, be concerned, and draw up conservation strategies dedi- 


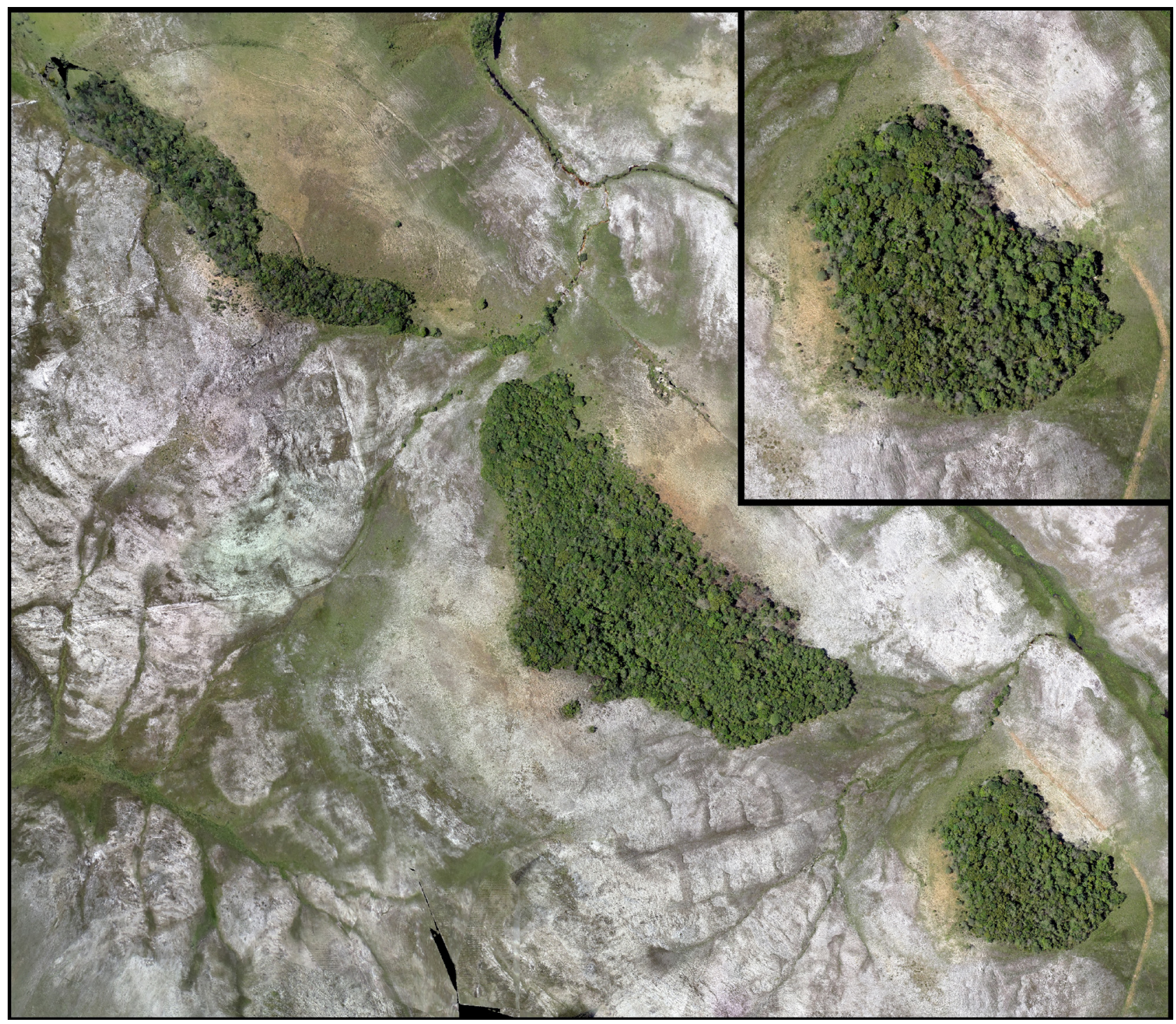

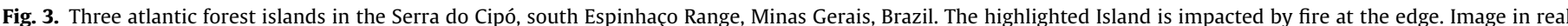

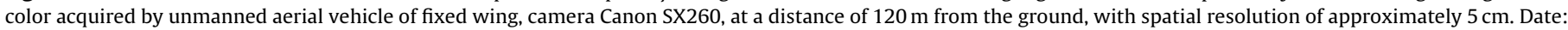
December 2016.

cated to this unique and increasingly threatened ecosystem, or they will be liable for the environmental and economic costs related to its degradation.

\section{Acknowledgements}

This study was in partial fulfillment of the Ph.D. requirements of Coelho M.S and supported by a fellowship provided by CAPES. We thank the grants and logistic support of the CNPq, PELD CRSC, Reserva Vellozia, and FAPEMIG. MSC receives a PDJ fellowship and FSN, GWF and LPCM receive a Research Productivity fellowship from CNPq. LPCM contribution was benefited by São Paulo Research Foundation (FAPESP) and Microsoft Research Institute (grant \#2013/50155-0) and FAPESP-VALE-FAPEMIG (grant \#2010/513070 ). We would like to thank two anonymous reviewers and the editor F.A.O. Silveira for their suggestions and comments. We are also grateful to T.S.F. Silva for helping with the figure of drone. The drone was operated by BD Borges and flight mission and mosaic processing by LF Cancian all supported by FAPESP.

\section{References}

Alvarado, S.T., Silva, T.S.F., Fornazari, T., Costola, A., Morellato, L.P.C., 2017. Drivers of fire occurrence in a mountainous Brazilian savanna: tracking long-term fire regimes using remote sensing. Ecol. Ind. 78, 270-281.

Arroyo-Rodriíguez, V., Rös, M., Escobar, F., Melo, F.P.L., Santos, B.A., Tabarelli, M. Chasdon, R., 2013. Plant b-diversity in fragmented rain forest: testing floristic homogenization and differentiation hypotheses. J. Ecol. 6, 1449-1458.

Barbosa, N.P.U., Fernandes, G.W., 2016. Rupestrian grassland: past, present and future distribution. In: Fernandes, G.W. (Ed.), Ecology and Conservation of Mountain-Top Grasslands in Brazil. Springer, New York, pp. 531-544.

Bond, W.J., Woodward, F.I., Midgley, G.F., 2005. The global distribution of ecosystems in a world without fire. New Phytol. 165, 525-538, http://dx.doi. org/10.1111/j.1469-8137.2004.01252.x.

Bond, W.J., 2008. What limits trees in C 4 grasslands and savannas? Annu. Rev. Ecol. Evol. Syst. 39, 641-659, http://dx.doi.org/10.1146/annurev.ecolsys.39. 110707.173411.

Bond, W.J., 2010. Do nutrient-poor soils inhibit development of forests? A nutrient stock analysis. Plant Soil 334, 47-60, http://dx.doi.org/10.1007/s11104-0100440-0.

Carstensen, D.W., Sabatino, M., Trojelsgaard, k., Morellato, L.P.C., 2014. Beta diversity of plant-pollinator networks and the spatial turnover of pairwise interactions. PLoS One 9, e112903.

Chase, J.M., Leibold, M.A., 2003. Ecological Niches: Linking Classical and Contempory Approaches. University of Chicago Press, Chicago.

Coelho, M.S., Fernandes, G.W., Pacheco, P., Diniz, V., Meireles, A., Santos, R.M., Carvalho, F.C., Negreiros, D., 2016. Archipelago of montane forests surrounded 
by rupestrian grasslands: new insights and perspectives. In: Fernandes, G.W. (Ed.), Ecology and Conservation of Mountain-Top Grasslands in Brazil. Springer, New York, pp. 129-153.

Coelho, M.S., Carlos, P.P., Pinto, V.D., Meireles, A., Negreiros, D., Morellato, L.P.C., Fernandes, G.W., 2018. Connection between tree functional traits and environmental parameters in an archipelago of montane forests surrounded by rupestrian grasslands. Flora 238, 51-59, http://dx.doi.org/10.1016/j.flora. 2017.04.003.

Dantas, V.L., Hirota, M., Oliveira, R.S., Pausas, J.G., 2016. Disturbance maintains alternative biome states. Ecol. Lett. 19, 12-19.

Federal Law № 11.428, http://www.planalto.gov.br/ccivil_03/_ato2004-2006/2006 lei/l11428.htm (Accessed 09 November 2016).

Federal Law $\mathrm{N}^{\mathrm{O}}$ 12.651/2012, http://www.planalto.gov.br/ccivil_03/_Ato20112014/2012/Lei/L12651.htm (Accessed 09 November 2016).

Fernandes, G.W., Goulart, F.F., Ranieri, B.D., Coelho, M.S., Dales, K., Boesche, N. Bustamante, M., Carvalho, F.A., Carvalho, D.C., Dirzo, R., Fernandes, S., Galett JR, P.M., Millan, V.E.G., Mielke, C., Ramirez, J.L., Neves, A., Rogass, C., Ribeiro, S.P., Scariot, A., 2016. Deep into the mud: ecological and socio-economic impacts of the dam breach in Mariana, Brazil. Nat. Conserv. 14, 35-45.

Fernandes, G.W., 2016. Ecology and Conservation of Mountain-Top Grasslands in Brazil. Springer, New York.

Figueira, J.E.C., Ribeiro, K.T., Ribeiro, M.C., Jacobi, C.M., França, H., Neves, A.C.O. Conceição, A.A., Mourão, F.A., Souza, J.M., Miranda, C.A.K., 2016. Fire in rupestrian grasslands: plant response and management. In: Fernandes, G.W. (Ed.), Ecology and Conservation of Mountain-Top Grasslands in Brazil. Springer, New York, pp. 415-448.

Galindo-Leal, C., Câmara, I.G., 2005. Mata Atlântica: biodiversidade, ameaças e perspectivas. Conservação Internacional, Belo Horizonte.

Guerra, T.J., Carstensen, D.W., Morellato, L.P.C., Silveira, F.A.O., Costa, F.V., 2016. Mutualistic interactions among free-living species in rupestrian grasslands. In: Fernandes, G.W. (Ed.), Ecology and Conservation of Mountain-Top Grasslands in Brazil. Springer, New York, pp. 291-310.

Hagen, M., Kissling, D.W., Rasmussen, C., Aguiar, M.A.M., Brown, L., Carstensen, D.W., Alves-Dos-Santos, I., Dupont, Y.L., Edwards, F.K., Genini, J., Guimarães, P.R., Jenkins, G.B., Jordano, P., Kaiser-Bunbury, C.N., Ledger, M., Maia, K.P., Marquitti, F.M.D., Mclaughlin, O., Morellato, L.P.C., Ogorman, E.J., Tr Jelsgaard, K., Tylianakis, J.M., Vidal, M.M., Woodward, G., Olensen, J.M., 2012. Biodiversity, species interactions and ecological networks in a fragmented world. Adv. Ecol. Res, 48, 89-210.

Hoffmann, W.A., Orthen, B., Vargas Do Nascimento, P.K., 2003. Comparative fire ecology of tropical savanna and forest trees. Funct. Ecol. 17, 720-726, http:// dx.doi.org/10.1111/j.1365-2435.2003.00796.x.

Hopper, S.D., 2009. OCBIL theory: towards an integrated understanding of the evolution, ecology and conservation of biodiversity on old, climatically buffered, infertile landscapes. Plant Soil 322, 49-86.

Jamoneau, A., Closset-Kopp, D., Decocq, G., 2011. Fragmentation alters beta-diversity patterns of habitat specialists within fores metacommunities. Ecography 35, 124-133.

Kareiva, P., Marvier, M., 2012. What is conservation science? Bioscience 62, 962-969.

Kolbek, J., Alves, R.J.V., 2008. Impacts of cattle, fire and wind in rocky savannas, southeastern Brazil. Acta Univ. Carol. Environ. 22, 111-130.

Leibold, M.A., Holyak, M., Mouquet, N., Amarasekare, P., Chase, J.M., Hoopes, M.F. Holt, R.D., Shurin, J.B., Law, R., Tilman, D., Loreau, M., Gonzalez, A., 2004. The metacommunity concept: a framework for multi-scale community ecology. Ecol. Lett. 7, 601-613.

Martinelli, G., Moraes, M.A., 2013. Livro Vermelho da Flora Brasileira. Andrea Jakobson Estúdio. Instituto de Pesquisas Jardim Botânico do Rio de Janeiro, Rio de Janeiro.
Meguro, M., Pirani, J.R., Mello-Silva, R., Giulietti, A.M., 1996. Estabelecimento de matas ripárias e capões nos ecossistemas campestres da cadeia do espinhaço Minas Gerais. Bol. Botânica da Univ. São Paulo 15, 1-11.

Miatto, R.C., Wright, I.J., Batalha, M.A., 2016. Relationships between soil nutrient status and nutrient-related leaf traits in Brazilian cerrado and seasonal forest communities. Plant Soil 404, 13-33.

Myers, N., Mittermeier, R.A., Mittermeier, C.G., da Fonseca, G.A.B., Kent, J., 2000 Biodiversity hotspots for conservation priorities. Nature 403, 853-858.

Oliveira, A.T., Fontes, M.A.L., 2000. Patterns of floristic differentiation among Atlantic Forests in Southeastern Brazil and the influence of climate. Biotropica $32,793-810$.

Pereira, G.C.N., Coelho, M.S., Beirão, M.V., Braga, R.F., Fernandes, G.W., 2017. Diversity of fruit-feeding butterflies in a mountain archipelago of rainforest. PLoS One, Accepted.

Ramos-Neto, M.B., Pivello, V.R., 2000. Lightning fires in a brazilian savanna national park: rethinking management strategies. Environ. Manage. 26, 675-684, http://dx.doi.org/10.1007/s002670010124.

Rehm, E.M., Feeley, K.J., 2015. The inability of tropical cloud forest species to invade grasslands above treeline during climate change: potengial explanations and consequences. Ecography 38, 1167-1175.

Rizzini, C.T., 1997. Tratado de fitogeografia do Brasil: aspectos ecológicos, sociológicos e florísticos. Âmbito Cultural Edições LTDA, Rio de Janeiro.

Rossatto, D.R., Hoffmann, W.A., Franco, A.C., 2009. Differences in growth patterns between co-occurring forest and savanna trees affect the forest-savanna boundary. Funct. Ecol. 23, 689-698, http://dx.doi.org/10.1111/j.1365-2435. 2009.01568.x.

Silveira, F.A.O., Negreiros, D., Barbosa, N.P.U., Buisson, E., Carmo, F.F., Carstensen, D.W., Conceição, A.A., Cornelissen, T.G., Echternacht, L., Fernandes, G.W., Garcia, Q.S., Guerra, T.J., Jacobi, C.M., Lemos-Filho, J.P., Le Stradic, S., Morellato, L.P.C., Neves, F.S., Oliveira, R.S., Schaefer, C.E., Viana, P.L., Lambers, H., 2016. Ecology and evolution of plant diversity in the endangered campo rupestre: a neglected conservation priority. Plant Soil 403, 129-152, http://dx.doi.org/10. 1007/s11104-015-2637-8.

Souza, D.T., 2009. Composição florística e estrutura dos capões de altitude no parque estadual do Rio Preto, Minas Gerais, Brasil, Master Thesis. Universidade Federal de Minas Gerais, Instituto de Biociências, unpublished results.

Staver, A.C., Archibald, S., Levin, S., 2011. Tree cover in sub-Saharan Africa: rainfall and fire constrain forest and savanna as alternative stable states. Ecology 92, 1063-1072.

Streher, A.S., Sobreiro, J.F.F., Morellato, L.P.C., Silva, T.S.F., 2017. Land surface phenology in the tropics: the role of climate and topography in a snow-free moutain. Ecosystems, http://dx.doi.org/10.1007/s10021-017-0123-2.

Tabarelli, M., Lopes, A., Peres, C., 2008. Edge effects drive tropical forest fragments towards an early successional system. Biotropica 40, 657-661, http://dx.doi. org/10.1111/j.1744-7429.2008.00454.x.

Thompson, J.N., 2005. The Geographic Mosaic of Coevolution. University of Chicago Press, Chicago, pp. 2005.

Valente, E.L., 2009. Relação solo-vegetação no parque nacional da Serra do Cipó, espinhaço meridional, Minas Gerais. PhD Thesis. Universidade Federal de Viçosa, Solos e Nutrição de Plantas, unpublished results.

Veldman, J.W., Buisson, E., Durigan, G., Fernandes, G.W., Le Stradic, S., Mahy, G., Negreiros, D., Overbeck, G.E., Veldman, R.G., Zaloumis, N.P., Putz, F.E., Bond, W.J., 2015. Toward an old-growth concept for grasslands, savannas, and woodlands. Front. Ecol. Environ. 13, 154-162, http://dx.doi.org/10.1890/ 140270 . 